\title{
Trzecia nowoczesność i koncepcja władzy instrumentalnej Shoshan Zuboff
}

\section{Third Modernity and Shoshan Zuboff's Concept of Instrumental Power}

The article describes the phenomenon of instrumental power in the third modernity. The work aims to define the theoretical framework of the third modernity and the new paradigm of exercising social control through instrumentalism. These concepts come from the works of Shoshan Zuboff and raise the issue of contemporary social relations in a globalised society.

Keywords: third modernity, surveillance capitalism, technopoly, progress, instrumental power, digital totalitarianism, Shoshan Zuboff

Słowa kluczowe: trzecia nowoczesność, kapitalizm inwigilacji, technopol, postęp, władza instrumentalna, totalitaryzm cyfrowy, Shoshan Zuboff

Nasze życie już do nas nie należy. Taki wniosek można wyciągnąć po lekturze najnowszej publikacji Shoshan Zuboff, Wiek kapitalizmu inwigilacji. Walka o przyszłość ludzkości na nowej granicy władzy ${ }^{1}$. Trzeba jednak dojść do tego wniosku etapami, stopniowo przyjmując argumentację i faktografię nagromadzoną przez autorkę.

Celem artykułu jest analiza wizji władzy instrumentalnej (instrumentalizmu) jako formy realizacji stosunków kontroli w trzeciej nowoczesności w ujęciu Zuboff. Praca ma za zadanie określenie istoty teoretycznej i konceptualnej instrumentalizmu oraz wytyczenie jego właściwości w kontekście trzeciej nowoczesności i totalitaryzmu cyfrowego.

Zuboff jest znaną i cenioną autorką publikacji z zakresu oddziaływania technologii na życie człowieka. Jej wcześniejsze prace: In the Age of the Smart Machine: The Future of Work and Power (1988 r.), The Support Economy: Why Corporations Are Failing Individuals and the Next Episode of Capitalism (2002 r.) oscylują wokół zagadnień, które porusza w najnowszej publikacji.

1 S. Zuboff, Wiek kapitalizmu inwigilacji. Walka o przyszłość ludzkości na nowej granicy władzy, tłum. A. Unterschuetz, Warszawa 2020. 
Wiek kapitalizmu inwigilacji jest obszernym opracowaniem problemu współczesnej zależności między człowiekiem, Internetem, a korporacjami tzw. Big Tech zwanych również GAFAM (Google, Amazon, Facebook, Apple, Microsoft). Praca jest wielowątkowa, ale odnosi się stale do problemu trzeciej fali², według Zuboff - trzeciej nowoczesności i koncepcji władzy quasi-totalitarnej, władzy instrumentalnej w postaci kapitalizmu inwigilacji.

Sama autorka definiuje kapitalizm nadzoru jako logikę i formę rynkowych działań funkcjonującą w świecie cyfrowym ${ }^{3}$. Kapitalizm inwigilacji zrodził się w momencie, w którym aktywność użytkowników cyberprzestrzeni stała się surowcem do produkcji danych behawioralnych ${ }^{4}$. Autorka nazywa to zjawisko nadwyżką behawioralną ${ }^{5}$, która ma za zadanie uczyć inteligentne maszyny predykcji ${ }^{6}$. Na podstawie tego surowca wywodzącego się z rozwoju i postępu technologii cyfrowych wykształciły się nowe formy sprawowania władzy, a także przesłanki by mówić o trzeciej nowoczesności.

Władza instrumentalna to nowa forma relacji społecznych. Zuboff przeciwstawia ją totalitaryzmowi cyfrowemu, który uznaje za pojęcie niedoskonałe, wywodzące się z niewiedzy. Autorka pragnie uzupełnić dyskurs i zrekompensować dotychczasowe błędne odczytania i interpretacje dotyczące relacji między koncernami cyfrowymi a człowiekiem. Cyfrowy totalitaryzm jest według Zuboff pojęciem niekonkretnym, utrudniającym zrozumienie istoty problemu, zacierającym poznanie przeciwnika i ostatecznie uniemożliwiającym walkę i neutralizację. Cyfrowy totalitaryzm uznaje Zuboff za pojęcie anachroniczne, które może posłużyć jako baza do tworzenia nowych ram definicyjnych7. W niektórych miejscach sama sobie przeczy. Wskazuje, że totalitaryzm opiera się na przemocy, kapitalizm inwigilacji zaś na modyfikacji behawioralnej. W istocie zespół argumentów i zjawisk opisywanych w pracy bardziej przemawia z totalnością trzeciej nowoczesności, niż chciałaby tego sama autorka.

Zuboff odrzuca cyfrowy totalitaryzm jako kategorię poznawczą i zastępuje go władzą instrumentalną, która: nie chce edukować ludzi, nie ma aspiracji duchowych, nie niesie ze sobą żadnej ideologii, nie ma wartości moralnych i etycznych. Władza instrumentalna nie eksterminuje ludności, lecz zadowala się danymi pochodzącymi ze śladów zostawionych z użytkowania sieci. Zuboff bardzo szeroko konceptualizacje pojęcie instrumentalizmu, który w istocie jest tylko elementem władzy.

Trzeba przyznać, że autorka używa modelu totalitarnego do swoich analiz, ale nie czyni tego do systemu władzy politycznej, lecz systemu władzy koncernów cyfrowych. Jest to jedna z tendencji funkcjonujących współcześnie oraz słuszne podejście do badań społecznych wymagających wyjścia od sprawdzonych struktur poznawczych. Jednocześnie model totalitarny jest obecnie nadużywany i przez to jego możliwości poznawcze rozciągane są na szeroki wachlarz zjawisk w oderwaniu od pierwotnego znaczenia ${ }^{8}$. Sama autorka

2 A. Toffler, Trzecia fala, tłum. E. Woydyłło, Warszawa 1997.

3 S. Zuboff, op. cit., s. 29.

4 Na ten problem zwraca uwagę Siva Vaidhyanathan. S. Vaidhyanathan, Antisocial Media. Jak Facebook oddala nas od siebie i zagraża demokracji, tłum. W. Mincer, K. Sosnowska, Warszawa 2018, s. 93-102.

5 Koncepcja nadwyżki behawioralnej pojawia się u Nicholasa Carrego. Por N. Carr, Płytki umysł. Jak Internet wpływa na nasz mózg, tłum. K. Rojek, Gliwice 2013, s. 193-194.

6 Mowa tu o Big Data i uczeniu maszynowym. M. Ford, Świt robotów. Czy sztuczna inteligencja pozbawi nas pracy?, tłum. K. Łuniewska, Warszawa 2016, s. 96 i n.

7 S. Zuboff, op. cit., s. 483.

8 D. Winczewski, Współczesne spojrzenie na teorię totalitaryzmu, „Studia Socjologiczno-Polityczne. Seria Nowa” 2019, nr 2, s. 116. 
podkreśla ten fakt i tym argumentuje wprowadzenie nowego pojęcia w postaci władzy instrumentalizacji.

Pierwszym problemem, na który wskazuje Zuboff, jest automatyzacja działań ludzkich i pewna ich rytualizacja. Autorka wskazuje na wyłonienie się nowego rodzaju władzy w postaci instrumentalizmu, który zna i kształtuje ludzkie zachowanie, dla realizacji celów innych niż cele jednostkowe. Władza ta wykorzystuje do tego architekturę sieciowych urządzeń, rzeczy i przestrzeni ${ }^{9}$.

Zuboff wskazuje, że kapitalizm inwigilacji jest formą ideologii totalitarnej wszechobecnej we wszystkich dziedzinach aktywności ludzkiej. Szeroko ukazuje psychologiczne aspekty totalności cyfrowej w postaci m.in: psychicznego znieczulenia, inercji, poddania się, oddania prywatności w ręce koncernów Big Tech, zmarginalizowania własnego znaczenia do źródła eksploatacji danych. W tych warunkach wzrastają skłonności sadystyczne i radykalne oraz bezduszność ${ }^{10}$. Z psychologicznego punktu widzenia instrumentalizm jest jednak absorbowany, ponieważ jest nieznany, kryje się za ścianą niewiedzy i braku jasnych reguł ${ }^{11}$. Kapitalizm inwigilacji to w rzeczywistości mechanizm społecznej kontroli, główne narzędzie instrumentalizmu i dominująca forma relacji w trzeciej nowoczesności.

Władza instrumentalna cechuje się dużą asymetrią wiedzy. Z jednej strony wiedza szczegółowa i tajemna znajduje się w rękach elit, z drugiej wiedza uniwersytecka jest rozdystrybuowana do granic „hipermerytokracji”12. Całkowite podporządkowanie nie jest konieczne, ponieważ jednostki same się podporządkowują. Wiedza, która była przynależna państwom i systemom edukacji, znajduje się w korporacjach Big Tech i jest przeciw państwom i społeczeństwom wykorzystywana. Teraz to prywatni przedsiębiorcy stoją za rozwojem i ewolucją świata, a nie wojny i konflikty jak miało to miejsce dotychczas ${ }^{13}$.

Zuboff prezentuje nawet konkretną wizję „końca historii” rozumianą jako metaforę w postaci światowego porządku masowego, zbiurokratyzowanego, zcentralizowanego, zestandaryzowanego ${ }^{14}$. Odnosi się przy tym do wizji Norberta Eliasa „społeczeństwa jednostek", gdzie dawniej zarezerwowane dla elit sektory takie jak wykształcenie wyższe, podróże, wysokie standardy życia, dostęp do dób konsumpcyjnych czy średnia długość życia stały się powszechne i dostępne dla wszystkich ${ }^{15}$. Autorka wskazuje, że żyjemy w momencie przełomowym, w którym dochodzi do zderzenia „wielowiekowej historii modernizacji z kilkudziesięcioletnią historią przemocy gospodarczej"16.

Koniec historii to koniec demokracji i systemu neoliberalnego w ujęciu Zuboff. Badaczka posiłkuje się przy tym opracowaniem Thomasa Piketty'ego, w którym dowodzi on, poprzez prawo akumulacji, że dysproporcje dochodów doprowadzają do antydemo-

9 S. Zuboff, op. cit., s. 20.

10 E. Lucas, Oswoić cyberświat. Tożsamość, zaufanie i bezpieczeństwo w Internecie, tłum. L. Lipińska, M. Dębski, Warszawa 2017, s. 40.

11 Znacznie dokładniejszy opis psychologicznych następstw funkcjonowania w cyberprzestrzeni: J.M. Twenge, iGen. Dlaczego dzieciaki dorastające w sieci są mniej zbuntowane, bardziej tolerancyjne, mniej szczęśliwe i zupełnie nieprzygotowane do dorosłości i co to oznacza dla nas wszystkich, tłum. O. Dziedzic, Sopot 2019, s. 127 i n.

12 J.H. Lorenzi, M. Berrebi, Przyszłość naszej wolności. Czy należy rozmontować Google'a... i kilku innych?, tłum. J. Nowakowska, Warszawa 2019, s. 100

13 P. Virilio, Prędkość i polityka, tłum. S. Królak, Warszawa 2008, s. 34.

14 S. Zuboff, op. cit., s. 54.

15 N. Elias, Społeczeństwo jednostek, tłum. J. Stawiński, Warszawa 2008, s. 340.

16 S. Zuboff, op. cit., s. 58. 
kratycznych działań i zwrotu przeciw liberalizmowi ${ }^{17}$. Tę samą tezę spotykamy u Alvina Tofflera, który opisując technokrację wskazał, że „jest w swej istocie niedemokratyczna"18 i będzie poszerzać granice niesprawiedliwości społecznej.

Władza instrumentalna realizuje się poprzez współczesny i przyszły ład światowy. Obecny ład narzuca państwom i społeczeństwom absolutyzm sił rynkowych, który gwarantuje kontrolę nad jednostkami silnie zatomizowanymi. Rozpad naturalnych grup i struktur społecznych umożliwił podporządkowanie jednostek systemowi liberalnemu, w którym swobodnie drenują przestrzeń cyfrową Big Tech ${ }^{19}$.

Zuboff kilkukrotnie sugeruje, że historia zatoczyła koło. Władza instrumentalna pozwoliła by bogactwo trafiło do wąskich elit, które wykorzystują je do sprawowania kontroli. Bogactwo to jest poza zasięgiem państwa, niedostępne dla zwykłych obywateli i posiada charakter patrymonialny. Instrumentalizm rodzi się nie przez państwo, lecz w nim i poza nim. Big Tech posiadają możliwości skupowania firm, a nawet całych sektorów gospodarek w państwach ${ }^{20}$.

Władza instrumentalna $\mathrm{w}$ trzeciej nowoczesności odbiera człowiekowi podmiotowość: „chcemy sprawować kontrolę nad własnym życiem, ale wszędzie ta kontrola jest udaremniana"21. Zuboff prezentuje niezmiernie pesymistyczny obraz współczesnych relacji między jednostką a koncernami kontroli i inwigilacji, dla których „jesteśmy tylko cyframi"22. W pewnych momentach widać jej niekonsekwencję rozróżnienia instrumentalizmu od cyfrowego totalitaryzmu. Odwołuje się do koncepcji cyfrowych tubylców, ale jej nie rozwija. Trzecią nowoczesność będą bowiem tworzyć owi cyfrowi tubylcy ${ }^{23}$ z całością bagażu doświadczeń sieciowych.

Zuboff odnosi się do trzeciej nowoczesności, której istotę ma pełnić instrumentalizm. Odrywa człowieka i współczesne relacje od ponowoczesności Zygmunta Baumana. Trzecia nowoczesność posiada dwie fazy. Pierwszą z nich był optymizm płynący z możliwości jakie dawały społeczeństwom i jednostkom nowe media, zwłaszcza media cyfrowe. Połączenie kapitalizmu i świata cyfrowego rodziło nadzieje na nowy kierunek świata, na trzecią nowoczesność w postaci utopijnej wizji integracji wartości demokratycznych z możliwościami szerszej partycypacji24. Niskie koszty partycypacji, szeroki dostęp do usług dawały możliwość społecznego, kulturowego rozwoju i skoku cywilizacyjnego. Szybko okazało się, że „siła grawitacji starych praktyk pociągnie je wstecz"25. Tą siłą jest to, co Pierre Bourdieu nazywa logiką komercji ${ }^{26}$. Wszelkie wytwory kulturowe nie ważne, czy po stronie

17 T. Piketty, Kapitał w XXI wieku, tłum. A. Bilik, Warszawa 2015.

18 A. Toffler, Szok przyszłości, tłum. E. Ryszka, W. Osiatyński, Warszawa 1974, s. 500.

19 Por. S. Vaidhyanathan, op. cit., s. 93-102.

20 Mowa tu o gospodarce algorytmicznej, pochłaniającej kolejne sektory. N. Bostrom, Superinteligencja. Scenariusze, strategie, zagrożenia, tłum. D. Konowrocka-Sawa, Gliwice 2016, s. 243.

21 S. Zuboff, op. cit., s. 70.

22 Ibid.

23 M. Spitzer, Cyfrowa demencja. W jaki sposób pozbawiamy rozumu siebie $i$ swoje dzieci, tłum. A. Lipiński, Słupsk 2015, s. 178 i n.

24 Pomija przy tym szereg przemian społecznych, takich jak zanik klasy średniej. Por. J. Bartlett, Ludzie przeciw technologii. Jak Internet zabija demokrację (i jak ją możemy ocalić), tłum. K. Umiński, Katowice 2019, s. 118119.

25 S. Zuboff, op. cit., s. 72.

26 P. Bourdieu, O telewizji. Panowanie dziennikarstwa, tłum. K. Sztandar-Sztanderska, A. Ziółkowska, Warszawa 2009 , s. $66,106,115$. 
twórców, czy odbiorców obarczone są zyskami" ${ }^{27}$. Drugą fazą trzeciej nowoczesności jest chwila obecna, okres marazmu i stopniowej akceptacji wobec zachodzących zmian, ale również czas rozeznania się w sytuacji. Trzecia nowoczesność będzie trwać w przyszłości jednak trudno przewidzieć jej dalszy kształt.

Trzecia nowoczesność działa na zasadach legitymizacji przemocy. W świetle i majestacie prawa wszelkie usługi, praktyki są zagwarantowane poprzez wyrażenie zgody i zawarcie umowy adhezyjnej. Umowy te narzucają użytkownikom warunki typu „wszystko albo nic". Preferencje użytkownika się nie liczą. Może korzystać z usług lub skazać się na wykluczenie. W obliczu takich warunków użytkownik jest na przegranej pozycji, umowy tego typu zaś sankcjonują brutalność inwigilacji Big Tech. Tego typu umowy oceniane są negatywnie, prezentują degradację człowieczeństwa, praworządności i instytucji państwowych, które winny stać na straży zasad moralnych. Przymus jest podstawową formą relacji między użytkownikiem a koncernem cyfrowym. Tu też pojawia się największa słabość rozróżnienia instrumentalizmu od cyfrowego totalitaryzmu - obydwa realizują się przez przymus.

Należy rozszerzyć powyższe założenie o uzależnienie odbiorców oraz o koncepcję lepkiej siły, którą posługują się cybernetyczni kapitaliści ${ }^{28}$. Usługi lepkiej potęgi są atrakcyjne dla odbiorców i nie pozwalają na wdrożenie mechanizmów wyjścia, a o ile takie funkcjonują, wiążą się z szeregiem negatywnych konsekwencji. Inną formą przymusu jest nadzór, który nie tylko posiada właściwości pomnażania kapitału, ale również zwiększania szczebli w hierarchii społecznej ${ }^{29}$.

Wizja władzy instrumentalnej ukazuje, że jednostka poprzez umowy typu „kliknij i zwiń" jest poniżana i odzierana z godności i prywatności. Następuje wywłaszczenie jej z jej własnego życia. Dochodzi do masowej skali dehumanizacji poprzez drapieżne warunki umów, które dają Big Tech nieograniczone prawa inwigilacyjne, umożliwiają potajemne praktyki, nie podlegają negocjacji ani regulacji ${ }^{30}$.

Zuboff wierzy w wizję i możliwość realizacji trzeciej nowoczesności na zasadach sprawiedliwości społecznej. W niej formy układów społeczno-cyfrowych zostaną zinstytucjonalizowane, jednostki, społeczeństwa zostaną wzięte w ochronę poprzez normy, zasady i zracjonalizowanie działań. Zniszczenie monopoli, działających na zasadzie asymetrii wiedzy i władzy jest celem organizmów państwowych ${ }^{31}$. Człowiek nie ma możliwości sprzeciwiania się utracie swoich wolności. Między nim a światem cyfrowym powinno pojawić się państwo. Walka między kapitałem nadzoru a państwem i społeczeństwem rozegra się w świecie cyfrowym o dominację, będzie to „bitwa o ludzką przyszłość" 32 .

Władza instrumentalna działa poprzez kapitalizm nadzoru, który z jednej strony wydobywa zasób społecznych „kliknięć” i „polubień”, z drugiej tworzy z nich analizy i per-

27 N. Postman nazwywa to zjawiso technopolem. N. Postman, Technopol. Triumf techniki nad kulturą, tłum. A. Tanalska-Dulęba, Warszawa 1995.

28 S. Vaidhyanathan, op. cit., s. 167.

29 M. Tegmark, Życie 3.0. Człowiek w erze sztucznej inteligencji, tłum. T. Krzysztoń, Warszawa 2019, s. 199-200.

30 S. Zuboff, op. cit., s. 76.

31 W przypadku monopoli Zuboff podaje podobne ujęcie ich funkcjonowania jak Jamie Bartlett, "chodzi o koncentrację władzy, danych i kontroli nad przestrzenią publiczną oraz o zdolność tych firm do poszerzania swoich wpływów w różnych branżach, zwłaszcza tych, które zajmują się infrastrukturą i technologiami przyszłości". J. Bartlett, op. cit., s. 141-142.

32 S. Zuboff, op. cit., s. 83 
manentny monitoring predykcyjny ${ }^{33}$, aż w końcu żąda i zabiera wolność do prywatności. Prywatność, a nawet intymność, jest tą walutą, którą jednostki i grupy płacą za nieograniczony dostęp do informacji. Pojawia się tu logika akumulacji, która łączy ze sobą logikę komercji Bourdieu z zasobami: mechanizmami przekształcania danych w zysk ${ }^{34}$.

W pewnych aspektach Zuboff nie wychodzi dalej niż poza rozważania Bourdieu. Wskazała, że kapitalizm nadzoru, jako współcześnie dominująca forma kapitalizmu w jej przekonaniu w państwach wysoko rozwiniętych, dokonuje zawłaszczenia tego, co Bourdieu określił polem produkcji kulturowej ${ }^{35}$. Zuboff przypisuje kapitałowi nadzoru logikę akumulacji, która dokonuje dehumanizacji, sprawia, że „jesteśmy obiektami, z których wydobywa się surowce”36, które służą predykcji, ponieważ „zaspokajanie rzeczywistych potrzeb ludzi jest mniej intratne, a zatem mniej ważne, niż sprzedaż prognoz ludzkich zachowań"37. Logika ekonomii i zysku jest podstawą rozwoju kapitalizmu inwigilacji i instrumentalizmu. Zauważył to już Toffler wskazując, że „technokratyczne planowanie jest ekonocentryczne" ${ }^{\prime 38}$.

Uczenie maszyn kosztem człowieka jest celem samym w sobie, ale i właściwością instrumentalizmu. Sztuczna inteligencja jest bez przerwy testowana na jednostkach, uczy się ich i od samego początku jest ukierunkowana przeciwko nim. Pochłanianie kolejnych ludzkich wolności przez sztuczną inteligencję jest celem, ponieważ SI „osiąga swój pełny jakościowy potencjał zbliżając się do totalności"39.

Instrumentalizm realizuje się przez swoistą formę wywłaszczenia cyfrowego, która w swój konceptualizacjo odnosi się do koncepcji akumulacji przez wywłaszczenie ${ }^{40}$. Potrzeby ludzkiego ciała, myśli, emocje, uczucia wcześniej indywidualne, stały się przedmiotem handlu. Ludzkie doświadczenie wykorzystywane jest do kreacji mechanizmów rynkowych, do predykcji zachowań. Ludzie w swych domach, rodzinach stali się „wygnańcami pozbawionymi praw do terytorium naszego własnego zachowania". Jednocześnie jednostki nie posiadają kontroli nad przedmiotem wywłaszczenia. Prywatność, wolność, intymność jest im zabierana na zawsze. Człowiek nie posiada prawa do samostanowienia ${ }^{41}$.

Wywłaszczenie posiada swój osobliwy mechanizm totalnego wyniszczenia, w postaci: wtargnięcia, przyzwyczajenia, adaptacji i przekierowania. Zuboff szeroko opisuje całość mechanizmu. Nie ma wątpliwości, że charakter przemian jest zjawiskiem totalnym. Odwołuje się tu do prac i przemyśleń Hanny Arendt. Jednak słaba kondycja człowieka i słabnąca pozycja państwa pozwalają na nieograniczony drenaż cyfrowej aktywności, z założeniem, że cyfrowe są przedmioty codziennego użytku oraz samo środowisko naturalne poddane digitalizacji: „świat jak i nasze życie są przetwarzane bez granic, jako informacja”42. Akty wywłaszczenia cyfrowego są formą kontroli nad jednostką, społeczeństwem, a jako takie przekładają się na formę władzy (obok państw lub nad państwami).

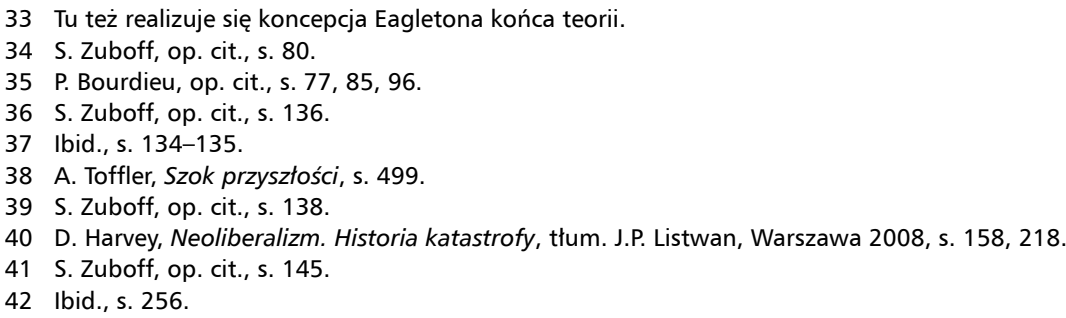


Władza instrumentalna to także rugowanie człowieka z jego naturalnych aktywności. Kolejną ofiarą po prywatności, wolności słowa, wolności wyboru będzie wolność pracy. Większość firm wybiera już inteligentną maszynę zamiast inteligentnego człowieka ${ }^{43}$. Dzieje się tak, ponieważ koszty utrzymania i ryzyko błędu są niskie, a efektywność wysoka. Tu trzeba zwrócić uwagę na koncepcję technopolu Neila Postmana, która kilkukrotnie nasuwa się w całości rozważań Zuboff. Zwłaszcza w odniesieniu wiedzy, kapitału do pracy, niektóre tezy nie straciły na znaczeniu, ale zyskały nowy wymiar. Dla Postmana liczy się wydajność, gdyż „rachunek techniczny pod każdym względem przewyższa ludzki osąd; że w rzeczywistości ludzkim sądom nie można ufać, ponieważ są skażone nieścisłością, dwuznacznością i zbędną złożonością". Postman wskazał, główną tezę kapitalizmu inwigilacji: „to, czego nie można zmierzyć, albo nie istnieje, albo nie ma wartości"44. Stwierdzenie to jest kwintesencją kapitalizmu inwigilacji u Zuboff.

Bogactwo form przemocy, o którym rozprawia Zuboff, należy jeszcze uzupełnić o przemoc symboliczną. Taki konglomerat założeń postawia dopiero stwierdzić, że instrumentalizm staje się systemem autopoietycznym, ponieważ posiadając władzę nad kulturą, kapitałem, danymi sam się napędza i sam przewiduje swój kolejny krok rozwoju. Nagromadzenie danych wyklucza teorie i przypuszczenia w momencie, w którym badaniu podlega cała populacja ${ }^{45}$. Można zatem stwierdzić, że człowiek w maszynie kapitalizmu inwigilacji jest zjawiskiem środowiskowym, a ślad, jaki zostawia po sobie, jest komunikatem, zasobem i formą kapitału.

Zuboff dokonuje zestawienia totalitaryzmu z instrumentalizmem. Jednocześnie należy wskazać, że zestawia koncepcję totalitaryzmu wywodzącą się z badań nad reżimami politycznymi i pomija szerokie spektrum rozważań nad cyfrowym totalitaryzmem. Kondensując rozważania nad trzecią nowoczesnością i władzą instrumentalną, można konkludować, że zjawiska te nie są tożsame z totalitaryzmem. Są to dwa zupełnie odmienne gatunki władzy. Instrumentalizm cechuje: mechanizm „Wielkiego Innego”, czyli algorytmu kształtującego ludzkie zachowania ${ }^{46}$; radykalna obojętność; dążenie do pewności wyników ${ }^{47}$; automatyzacja działań; kontrola wiedzy i dostępu do niej; osobliwość środków niepodlegających władzy politycznej; bazowanie na matematycznej, algorytmicznej kontroli i predykcji; globalizacyjne ujednolicanie, budowa świadomości zbiorowej; działanie na populacji ludzkiej (nie grupie, lecz całości populacji on-line); przymusie podłączenia i budowie zależności ${ }^{48}$. Tak rozumiana władza instrumentalna jawi się jako instrumentarium globalnego zarządzania.

Czy rzeczywiście władza instrumentalna różni się do totalitaryzmu cyfrowego? W rozważaniach Zuboff możemy pod tym względem dopatrzyć się kilku nieścisłości. Największe zastrzeżenie budzi zestawienie instrumentalizmu nie z totalitaryzmem cyfrowym, lecz totalitaryzmem politycznym ${ }^{49}$, gdzie różnice jawią się wyraźnie. Jednak sama autorka wskazuje, że instrumentalizm jest totalitaryzujący, a w przyszłości wzrost

44 N. Postman, op. cit., s. 68.

45 T. Eagleton, Koniec teorii, tłum. B. Kuźniarz, Warszawa 2012, s. 33.

46 S. Zuboff, op. cit., s. 513.

47 lbid., s. 520.

48 Ibid., s. 514-541.

49 Lepszym rozwiązaniem byłoby zestawienie z liberalnym totalitaryzmem, który zakłada, że porządek ekonomiczny wypracowuje uprzywilejowaną pozycję koncernom akumulującym kapitał. 
władzy instrumentalnej jest oczywiście zamierzony jako bezkrwawy zamach stanu. Zamiast przemocy wymierzonej w nasze ciała instrumentalna trzecia nowoczesność działa bardziej na zasadzie oswajania [...] stopniowym eliminowaniu chaosu, niepewności, konfliktów, nienormalności i niezgody na rzecz przewidywalności, autonomicznej regularności, przejrzystości, konfluencji, perswazji i pacyfikacji ${ }^{50}$.

Mimo wszystko cyfrowość jako remedium postępu okazała się mitem. Władza instrumentalna jawi się jako źródło cierpień ${ }^{51}$, tak samo, jak władza totalitarna. Zuboff nie podejmuje szerzej problemu przyszłych wpływów polityki na postęp technologiczny. Podobnie robią Max Tegmark (Życie 3.0) czy Nick Bostrom (Superinteligencja).

Postęp ujmowany tu jako władza instrumentalna w trzeciej nowoczesności jest silnie antydemokratyczny. Zuboff unikając otwarcie zwrotów odnoszących się do totalitaryzmu nie podejmuje istoty zmian społecznych, a przecież „totalitarne niebezpieczeństwo wykluwające się w łonie społeczeństw jest bardziej fundamentalne i bardziej decydujące niż niebezpieczeństwo związane z wyścigiem zbrojeń" 52 .

Wprowadzone przez Zuboff pojęcia władzy instrumentalnej i trzeciej nowoczesności mają swoją genezę we wcześniejszych rozważaniach teoretycznych. W przypadku Zuboff mamy do czynienia z dokładną konceptualizacją instrumentalizmu. Tym zjawiskiem stara się zastąpić funkcjonujące w literaturze pojęcie totalitaryzmu cyfrowego. Jest to podejście słuszne, a szerokie studium faktograficzno-konceptualne zaproponowane przez autorkę Wieku kapitalizmu inwigilacji pozwala na definiowanie zjawisk zachodzących w przestrzeni cyfrowej właśnie mianem instrumentalizmu.

W stosunku do trzeciej nowoczesności należy mieć zastrzeżenia. Pojawiająca się wizja teraźniejszości jest jednowymiarowa, opisuje człowieka w jego relacji z siecią, ze światem cyfrowym. Trzecia nowoczesność wynika z dużych dysproporcji w świecie rozwiniętym i jest obecna w państwach wysokorozwiniętych jako zjawisko, ale nie wszechogarniające. Trzecia rzeczywistość obejmuje tylko te społeczności, w których rozwój usług cyfrowych jest zaawansowany.

Powyższe zjawiska wywodzą się z nurtu neomarksistowskiego. Autorka nie ukrywa tego faktu kilkukrotnie odwołując się do Marksa i neomarksistów. Wizja trzeciej rzeczywistości Zuboff jest wizją świata kapitalistycznego przez pryzmat społeczeństwa klasowego. Ostateczną konstatacją jest uznanie, że nasze życie jeszcze do nas należy, ale władza instrumentalna i trzecia nowoczesność pozbawią nas i tego ciężaru.

\section{Bibliografia}

Bartlett J., Ludzie przeciw technologii. Jak Internet zabija demokrację (i jak ją możemy ocalić), tłum. K. Umiński, Katowice 2019.

Bostrom N., Superinteligencja. Scenariusze, strategie, zagrożenia, tłum. D. Konowrocka-Sawa, Gliwice 2016. 
Bourdieu P., O telewizji. Panowanie dziennikarstwa, tłum. K. Sztandar-Sztanderska, A. Ziółkowska, Warszawa 2009.

Carr N., Płytki umysł. Jak Internet wpływa na nasz mózg, tłum. K. Rojek, Gliwice 2013.

D. Harvey, Neoliberalizm. Historia katastrofy, tłum. J.P. Listwan, Warszawa 2008.

Eagleton T., Koniec teorii, tłum. B. Kuźniarz, Warszawa 2012.

Elias N., Społeczeństwo jednostek, tłum. J. Stawiński, Warszawa 2008.

Ford M., Świt robotów. Czy sztuczna inteligencja pozbawi nas pracy?, tłum. K. Łuniewska, Warszawa 2016.

Hassner P., Koniec pewników. Eseje o wojnie, pokoju i przemocy, tłum. M. Ochab, Warszawa 2002.

Lorenzi J.H., Berrebi M., Przyszłość naszej wolności. Czy należy rozmontować Google'a... i kilku innych?, tłum. J. Nowakowska, Warszawa 2019.

Lucas E., Oswoić cyberświat. Tożsamość, zaufanie i bezpieczeństwo w Internecie, tłum.

L. Lipińska, M. Dębski, Warszawa 2017.

Piketty T., Kapitalizm w XXI wieku, tłum. A. Bilik, Warszawa 2015.

Postman N., Technopol. Triumf techniki nad kulturą, tłum. A. Tanalska-Dulęba, Warszawa 1995.

Spitzer M., Cyfrowa demencja. W jaki sposób pozbawiamy rozumu siebie i swoje dzieci, tłum. A. Lipiński, Słupsk 2015.

Tegmark M., Życie 3.0. Człowiek w erze sztucznej inteligencji, tłum. T. Krzysztoń, Warszawa 2019.

Toffler A., Szok przyszłości, tłum. E. Ryszka, W. Osiatyński, Warszawa 1974.

Toffler A., Trzecia fala, tłum. E. Woydyłło, Warszawa 1997.

Twenge J.M., iGen. Dlaczego dzieciaki dorastające w sieci są mniej zbuntowane, bardziej tolerancyjne, mniej szczęśliwe i zupełnie nieprzygotowane do dorosłości $i$ co to oznacza dla nas wszystkich, tłum. O. Dziedzic, Sopot 2019.

Vaidhyanathan S., Antisocial Media. Jak Facebook oddala nas od siebie i zagraża demokracji, tłum. W. Mincer, K. Sosnowska, Warszawa 2018.

Virilio P., Prędkość i polityka, tłum. S. Królak, Warszawa 2008.

Winczewski D., Współczesne spojrzenie na teorię totalitaryzmu, „Studia Socjologiczno-Polityczne. Seria Nowa" 2019, nr 2, s. 101-119.

Zuboff S., Wiek kapitalizmu inwigilacji. Walka o przyszłość ludzkości na nowej granicy władzy, tłum. A. Unterschuetz, Warszawa 2020.

dr Piotr Lewanowski jest adiunktem w Katedrze Geopolityki Wydziału Bezpieczeństwa Akademii Sztuki Wojennej.

e-mail: p.lewandowski@akademia.mil.pl

Data zgłoszenia artykułu: 8 lutego 2021

Data przyjęcia do druku: 22 lutego 2021 